\title{
INCREASING REGIONAL COOPERATION TO PROMOTE INFRASTRUCTURE DEVELOPMENT AMONG SOUTHEAST ASIAN COUNTRIES
}

\author{
Perdana Miraj $^{1^{*}}$, Zulkarnain $^{1}$, Fadhilah Muslim $^{1}$ \\ ${ }^{1}$ Center for Sustainable Infrastructure Development, Faculty of Engineering, Universitas Indonesia, \\ Depok 16424, Indonesia
}

South East Asia has transformed from low economic income into prospectus global economic player during the last decades through industrialization strategies, human capital expansion, and infrastructure investment. Many cities in this region promote infrastructure development across various sectors for instance roads, railways, ports, and airports. This attempt expected to improve accessibility, inter-regional connectivity among cities in the country and significantly reduce logistics costs in the longer term. Improving the level of competitiveness through this action is, therefore, crucial to level up other developed countries in term of economic activities.

Despite a growing number of development in developing countries, several challenges are facing the global community today. Cities in South East Asia are now more vulnerable to catastrophic events. Earthquake followed by tsunami and liquefaction in Palu, Sulawesi Island in earlier months reminds us on similar events that struck Aceh province and other parts of the region in 2004. Consequently, cities not only those along the coastline but also in the hinterland area, must adopt a sustainable pathway and building a resilience city. The exponential growth of the internet and technology during the past decades shall be used for mitigating natural disaster and generate livable cities for its inhabitant.

Challenges from climate change and biodiversity anomalies caused by human activities in urban areas have costs us great danger. This planet should be reduced from human ecological footprint to preserve humanity in the future. Investing into an energy efficiency device or encouraging renewable energy generate substantial returns which have multiple beneficial impacts - not just on greenhouse gas reductions, but on the economic development of a nation. Cities that reduce the energy emission by 20-30 percent still might gain significant growth through a green investment. It also potentially provide many jobs in urban areas and thus stimulate economic activities.

Last, infrastructure development also related to the financial capability and economic impact of a nation. For developing countries in South East Asia, spirit for building new infrastructure facing an obstacle in term of a limited state budget. Initiating a partnership with a business entity from private, state-owned enterprise and other interested parties is one way to overcome the lack of infrastructure funding resources and accelerate infrastructure development not only in the urban but also rural area. Government support through comprehensive policy and regulations expected to increase strategic alliance between public and private sector.

*Corresponding author's email: perdana.miraj@ui.ac.id 
In this special issue of CSID Journal of Infrastructure Development, we kindly present twelve papers from the first CSID AUN-SCUD International Conference on Sustainable Infrastructure and Urban Development (CAIC-SIUD) 2018. The conference was organized by The Center for Sustainable Infrastructure Development (CSID) Faculty of Engineering, Universitas Indonesia in collaboration with ASEAN University Network (AUN).

The conference covers cities and its development in the aspect of technical, financial and economic, social and environmental impact. The conference attempt to connect academics with businesses and governments that interested in the development of ASEAN sustainable cities and share current experiences and research results on all aspects of urban development.

The first paper, written by D. Daniel and P. Habsari attempt to analyze the current regulation of public participation in Indonesia to identify possible informational asymmetry that might give a barrier to effective monitoring. They argued that community participation proves to educate and empower the community in environmental management and supported to the increasing of public participation.

The second paper, written by F. Ali, D.L. Lestari, M.D. Putri, and K.N. Azmi investigates green city development by taking Serpong Urban Residential as the case study. Their findings argued that reduce raw natural resources, recharge depleted natural resources and utilizing renewable energy are the key to creating green cities.

The third paper, written by $\mathrm{C}$. Mubin examines a model for analyzing the effect of debt financing in infrastructure development, and develop the proposed financing scheme to reduce the adverse effects. The author argues that accelerating infrastructure development has a positive effect on Indonesia's economic growth despite an adverse effect in the increased debt.

The fourth paper, written by S.A.S. Alyani and Herlily evaluates a sense of place through tactical urbanism by taking into account a case study in Jakarta. The findings show that actors' active role and interactions may increase the sense of place.

The fifth paper, written by N. Bramono, A. Kim and M.A. Berawi, discuss critical factors to expedite energy efficiency retrofits (EER) framework using alternative financing. They argued that appropriate incentives for specific building types might contribute to the success of energy efficiency savings. The capacity and financial ability should also be considered to achieve EER from the existing building.

The sixth paper, written by A. Devina and A. Gamal elaborates uneven development that occurs between the street vendor and other trade area managed by building owner. They found out that trade area that managed by building owner has higher potential to gain revenue due to better concept and facilities. Thus, improvement should be conducted by a street vendor to gained interest from the customer.

The seventh paper, written by D. Lutfiyah and Herlily presents the pattern of the domestic negotiating spaces in one of the kampungs in Jakarta. The result illustrates that negotiating spaces that occurred in the case study was not accidental and in contrary create social space and interaction among the people.

The eighth paper, written by F. Ali, D.L. Lestari, M.D. Putri, and K.N. Azmi analyze the water needs in Depok City. Their findings argued that water resources in the city could be optimized and environmental campaign program might contribute to increase public awareness of water management.

The ninth paper, written by H. Pujowidodo, A.I. Siswantara and Budiarso examine bio-micro high power density generation system to achieve Zero Energy Building (ZEB). They argued 
that improved parameters through velocity and mass flow generate expected output that can contribute to the development of ZEB in the future.

The tenth paper, written by J.A. Kasim, M.J.M. Yusof and H.Z.M. Shafri review the benefits of urban green space (UGS) development in the contemporary of urban sustainability. Their findings show that green space is not only related to improving health issue but also can be a device to stabilize our city's ambiance. The authors suggest green space to be developed in the community's cultural and relate to the context of its spatial design.

The eleventh paper, written by W.K. Soedarsono, N. Victoryka, R.A. Yogaswara, H.I. Imanullah explores the land use transformation and changes of urban built heritage character and appearance of historical residential neighborhood areas in Jakarta and Bandung. They argued that to conserve and to retain the vital aspect of historic neighborhoods, cultural heritage laws should embrace 'townscape values' which associates not only the individual attributes of a building but also the contribution the area brings to a group of buildings, street or townscape.

The twelfth paper, written by L. Prayogi and A.F. Satwikasari explores Bus Rapid Transit (BRT) system passengers' modal shift considerations. They found out that components of BRT service quality and components of the built environment around BRT may affect passengers' consideration when shifting their mode of transport.

We hope that this special edition of CSID Journal of Infrastructure Development may propose insightful knowledge and brings benefits for our reader. We welcome any comments or inquiries that you may have concerning the direction and the content of the journal. We also invite you to join us by sending your work for future consideration.

Warmest regards,

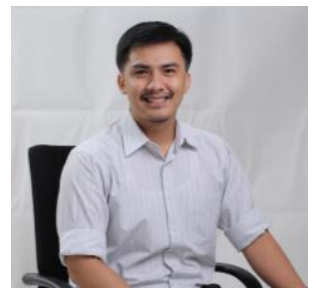

Perdana Miraj Managing Editor

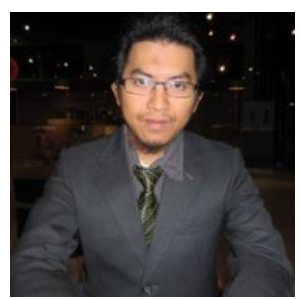

Zulkarnain Editor-in-chief

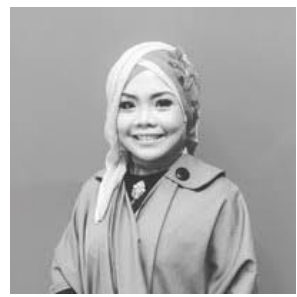

Fadhilah Muslim Managing Editor 